\title{
TO MADECENG PANGAMPE: SCHOOL TEACHER EFFORTS IN THE FORMATION OF CHARACTERS BASED ON LOCAL CULTURE IN BARRU DISTRICT
}

\author{
Nurdiati, Mahmud Tang, Supriadi Hamdat, Yamin M. Sani. \\ DOI: 10.31364/SCIRJ/v6.i10.2018.P1018574 \\ http://dx.doi.org/10.31364/SCIRJ/v6.i10.2018.P1018574
}

\begin{abstract}
This article aims to explain how the process or practices of instilling local cultural values in formal learning at school. At the same time will also see what the acceptance or internalize local cultural values through formal education in junior high schools in Barru Regency. The research was conducted at Tanete Rilau 3 Middle School in Barru Regency. The results showed that junior high school students had local cultural values embedded in each subject held. In addition, various kinds of teacher efforts are carried out in the teaching and learning process to continue to socialize these local cultural values.
\end{abstract}

Keywords: Madeceng, Character, Local Culture, Education.

\section{A. Introduction}

Education for character building has become a national issue that at least began to be echoed after the reformation when we re-realized the importance of this in order to prevent actions that could damage themselves, their families, and especially the people at the national level. But actually the intentions and objectives have long been echoed, or rather insinuated, mainly through the work of Koentjaraningrat (1974) where he described five attitudes that hinder development, namely; the attitude of underestimating the quality of one's own work (local products), the attitude of passing away or claiming to have the ability in every field that actually does not become a specification, an attitude of not believing in oneself, an undisciplined attitude, and an irresponsible attitude. The attitude itself, as the five attitudes described by Koentjaraningrat, is based on the character of each individual, which character is; "Feelings (sentiments) and the dominant beliefs of an individual at all times, with which his attitude to himself and his environment depend ${ }^{1 "}$ (Gordon, 2005).

A child and teenager or student called a student has a personal culture, in which case and also collective culture has a function as "a set of rules, morals and methods related to interactions that bind a group of people" (Flanagan, 2002). Or that in the context of education for character building is intended as a basis for understanding, the basis of assessment, from our various attitudes towards something which is then imprinted in various forms of action. If the character becomes an attitude reference and then imprinted in action, character education is understood as; "deliberate efforts to help people understand, care, and act on ethical values".

"Business intentionally" means that, it is understood that a person or student has had experience, knowledge, and desires, or what is meant in terms of personal culture, so a special effort is needed which is intentionally carried out in order students have an understanding the same as in general (community [in the narrow and broad sense] where he is), or understanding that is in accordance with the norms, values, rules, and culture of his community. The meaning is in accordance with the concept of "Tomadeceng Pangampe". The same understanding as in general is then expected to shape the attitude of students, or at least be a corridor or guidance in attitude. In other words, the educational process is for character formation through enculturation or; "A process that bridges individuals to their communities and their expectations (expectations) and psychological desires and characterized actions" (Eller, 2009).

Considered able to shape the character of students through understanding regarding to various things, which with these understandings he is expected to be able to limit themselves from attitudes that are not in accordance with the general, which is the appropriate attitude in general is then imprinted in actions that are also considered in accordance with generally. This is the same as Bugis cultural values in instilling the character of children with the term "Madeceng Pangampe".

\footnotetext{
${ }^{1}$ Original text; dominant sentiments and beliefs of an individual at any given time, whereby his attitude to himself and his environment is determined
} 
Furthermore, "our attitude is a product of our history and culture" (Flanagan, 2002), in the sense that it refers to history and culture delivered in the process of enculturation or socialization. This statement can be assumed as the basis of why the values of local culture such as appakeadekeng are imprinted in the attitude of the brotherhood, sipakainge, and sipakalebbi ${ }^{2}$, and are also "made" a student model in the hope that students understand the civilized or commendable attitudes in their environment ( especially in bugines society). Likewise, the student model relates to the status of noble or distinguished noble families, and includes the planting of siri 'na pesse (Shame and brave) ${ }^{3}$ attitudes regarding various actions that are considered to maintain the dignity of the family, which shows that our attitude does make things related to history or culture of the past still be chosen in our various actions, in certain contexts. Why do I call it in certain contexts? Because for example related to legal processes, we no longer refer to customary law or traditional law or law in our local culture, as in areas where the Makassar tribe lives there is the term 'lalang lipa' ${ }^{4}$ as a form of final action if a dispute or dispute does not get agreement in deliberation. Likewise in the case of cross-sectionalism, the current events no longer place traditional law as a problem-solving process but rather choose positive law.

This shows our public awareness of state law and the presence of law enforcement officers. On the totally different side, that is, referring to our daily actions, it also does not refer to the practice of local cultural values because they are assumed to no longer fit contemporary conditions and situations. The reference to our daily actions (both personally and collectively) at this time is a history and culture that happened massively in our country in the past decade, or rather at the end of the 20th century, which was called the reform era. If in the kingdom era - as a term that I use to refer to local cultural values such as the example above or as a term that refers to conditions where the trademark is local cultural values - used in certain contexts that we can categorize refer to interactions Regarding the characteristics or characteristics of our tribe, the reform era where the trademark is the freedom to express aspirations, freedom of expression, the modernization of technology, especially informatics, is used as a reference in our daily actions.

As an example in accordance with the present reality, three actions that have implications for damage to self, family, and even society are bullying, brawls, and free sex. Bully, as we know, occured at the basic level (KPAI, 2014) to the level of universities. Bully cases at the elementary level (Elementary School) in Indonesia are very large, of which one of them which is warm news is the case that happened to a girl in Bukit Tinggi which was recorded intentionally and later revealed since it was spread in cyberspace (Republika, 2014). Bully cases also occur in an elementary school child in Makassar, who was forced by his playmates to eat ice blocks with the threat of not being accompanied if they did not, which then led to stomachache and fear of going to school (this story is based on the narrative of parent boy's to me). However, bully cases at the basic level do not only occur in our country, even in Japan - where bully is called ijime - this is the most frequent case occured (Richard Susilo in tribunnews.com, 2014).

What has been explained previously shows that characters which, although considered to be unconscious, can be formed by providing understanding in the form of verbal teaching and action through enculturation of culture, both through formal and informal education, in the hope that students (students, children and adolescents) have an attitude that in accordance with the cultural system and applied in action. Therefore, this article will discuss about (1) What are the efforts of teachers in planting cultural and religious values in character building for children in the present context; (2) The extent of acceptance (internalization) of children in the process of instilling values for character formation.

\section{B. Literature Review}

\section{The Value of Buginese Culture as a Character Builder}

Makkedai Puang Maggalatung, Lempu naaca, Iyanaritu madeceng riparaddei riwatakkalee, Iyatonaritu temmassarang dewata Seuwae. Naiya likes to accuse me, I mean, mitae munri, I don't know. Naiya nappogau complete madeceng napogaui. Narekko engkai maja, ajasija mupogaui matti jana riko. The meaning: Puang Ri Maggalatung Said, honesty and intelligence, that is what is most instilled in us, that is also what is not sevarated from the Single Gods. What is called clever is the ability to see the end (effect) of action. And doing it is good, you must not do it, because the will return to you.

\footnotetext{
${ }^{2}$ Translation; Appakeadekeng means civilized attitude. Sipakatau means mutual understanding. Sipakainge 'means reminding each other. Sipakalebbi 'means mutual respect. All three are attitudes that are generally taught or found in areas where the Bugis tribe lives.

${ }^{3}$ Translation; shame and solidarity. Referring to the notion of self-esteem based on the dignity of fellow families (as a family), fellow villages (village), and all tribes (fellow tribes) (Mattulada, in Indonesian Anthropology, 1991).

${ }^{4}$ Translation; Stabbing in a sarong. Usually this is done when there is no agreement between the conflicting parties, so that each person sends a person who is believed to be a representative to then stab each other in a sarong, with the agreement that who lives or can be held strong will be the party to the dispute.
} 
The main values of Buginese culture are formulations that are considered as values that encourage the Bugis community to have its main character. The following are descriptions of the Bugines cultural values that shaped the character of the community:

a. Honesty Value (Lempu '): In Indonesian it means honest, same as straight as the opposite of crooked. In various contexts this word means sincerity, right, good or fair. So the opponents of these words are cheating, cheating, lying, treason, frivolity, bad, deceit, persecution, and the like.

b. Compliance Value (Asitinajang): In Indonesian it means Compliance, appropriateness, feasibility, this word comes from "tinaja" which means suitable, adjust, appropriate or appropriate.

c. Getteng value: In Buginese language, constancy is expressed by Getteng. Besides being steadfast, getteng also means obeying principles, being faithful to beliefs, strong and tough in stance, and tightly holding onto something

d. Shyness (Siri '): In Indonesian it means embarrassment shame which is an institutionalized custom and still has a large influence on the culture of the life of the people of South Sulawesi.

e. Value of Social Security (Assitulungeng): Mutual assistance or existence of help

\section{Character Concepts}

Characters come from the Greek characters that are rooted in diction "karasso" or "charassein" which means carving or carving, whereas in Latin the character means to distinguish signs. Indonesian, characters in Indonesian can be interpreted as psychiatric / attitude/behavior. Character in English is written character, psychologically can be interpreted as a person's personality which is reviewed based on ethical or moral, such as honesty someone usually has to do with relative traits.

It can be concluded that the character is related to positive moral strength, and not a negative connotation. Individuals or people with character are people who have positive moral qualities. Character is something that is unique only to individuals or to a group, nation. Character is the basis of cultural awareness, cultural intelligence and is also a cultural glue.

\section{Research Methods}

The approach used in research (data collection to data analysis) is a phenomenological approach in which there are qualitative methods. The phenomenological approach is an approach that "concerning the study of experience from the perspective of an individual (the perpetrator). The appropriate research strategy to be applied later is ethnographic studies. Etymologically, ethnography is composed of two syllables in Greek, namely: ethnos which means tribes or society in a narrow and broad sense (people and society), and; graphy which means a picture, and therefore ethnography can be simply understood as a description of the culture of a society. The research for this dissertation was conducted in Barru Regency - South Sulawesi Province. Data collection used was in-depth observation, in-depth interviews, and library studies.

\section{Practices of Planting Values in Forming Character Students.}

According to Basri as the principal of Tanete Rilau 3 Middle School in Barru District, the improvement of learning strategies in the framework of planting values in forming the character of students in Tanete Rilau 3 Middle School in Barru Regency is as follows:

a) Management of First Face Activities.

The success of a learning begins with some informative activities from the teacher to students or from students to the teacher. The informative activity is carried out in an organized manner at the beginning of the first meeting or with the first faceto-face term, so that the learners know exactly what capabilities the learners should have after following the subjects in a certain period of time. So that the activities that need to be organized in the learning process at Tanete Rilau 3 Junior High School in Barru Regency are; First Detection of Characteristics of Students. Second, Submission of outlines of program subjects which include the content framework or often called epitome, in writing, RPP, student textbooks and others.

Third, Submission of general purpose of learning, and fourth Submission of learning strategies, to deepen learning material. This is reflected in the observation that the teachers convey to the learners how to technically establish a subject. The subject matter intended is the subject of the Fifth PAL study, Submission of the scoring system. Submission of assessment techniques, according to Muhlis about how rights and obligations in carrying out tasks related to assessment. 
Based on the results of the interview above with regard to the assessment, an interpretation can be obtained that the religious teacher of the State Junior High School 3 Tanete Rilau in Barru Regency conducted an evaluation with an oral and written form to the students. The measured taxonomy includes the cognitive, affective and psychomotor domains. In the context of the assessment, in quantity it means how many times students are assessed from each aspect of the assessment, the informant does not convey to students. But in writing as stated in each subject, all of them included the form of assessment, including the items to be given to students. Inclusion of assessment aspects, is the standard format used at all levels of Tanete Rilau 3 Middle School in Barru Regency.

The assessment aspects intended in the PSP are two, namely the first assessment process, the second is the acquisition of learning outcomes. Both forms of assessment were explained by informants, such as the results of interviews, namely that the assessment process meant meaning in evaluating the performance of students, forever students were blamed if for example the performance displayed was low, because it could be caused by lack of teacher's ability to make test instruments. Understanding like this means that the teacher can improve his assessment instrument. In the provision for daily assessments it is recommended for all teachers to carry out evaluation questions. Then for the assessment of learning outcomes are the results of the performance of students in accordance with the questions given to them.

The reference book and learning resources are an important part of one of the efforts to broaden knowledge horizons, both to teachers and to students. The results of the observation showed that when the informant held the first meeting no one mentioned the reference book that would be used as additional material or a comparison of the textbook used. Information about the reference book in writing is included in the PSP which is often mentioned as limited to the textbooks from the school and translations of the Quran and Hadiths. Information about other sources, verbally the Rl correspondent once mentioned how many books were related to the subject matter (for example, about halal and good food, for second grade). But overall all the informants mentioned information about learning resources. In this context the informant revealed the results of the following interview:

"So far, I have informed about the books that can be used as references by students, because we see that most students seem to be able to hold other books besides textbooks, even though the tendency of Tanete Rilau 3 Middle School students in Barru Regency is already felt they had enough guidance books circulated by the school. (Basri, Principal of Tanete Rilau Middle School 3)”

From the information above, it can be understood that the religion teacher of the State Junior High School 3 Tanete Rilau, Barru Regency, chose the delivery of information relating to reference books and other learning resources to students. This is based on the consideration that students are able to overcome it.

b) Organizing activities for the delivery to students every face to face

Organizing the delivery of learning on the topic discussed is a routine activity carried out by all the teachers in the Tanete Rilau 3 Junior High School in Barru District in conducting a series of learning stages, he mentions the term "instructional events". In this section sequentially will be stated: (1) organizing activities at the preliminary stage of learning, (2) organizing activities at the core of learning, (3) organizing activities for closing learning, (4) teacher attitudes during the learning process, (5) using methods of teaching and using media, and (6) classroom atmosphere when learning takes place.

Organizing in the initial activities entering the class room can be organized into several activities, in this study the intended activities are (1) greetings, (2) techniques of attracting students' attention, (3) delivery of specific learning objectives, and (4) linking previous subjects and new topics.

(1) greeting expression

One of the principles of communication in Islamic societies is to start greeting. This communication applies to all types of social social activities. In the implementation of activities in schools for Islamic teachers are obliged to socialize greetings. As a result of the observation of students, most of the informants say twice greetings, namely at the beginning of each lesson and the end of learning. This greeting is pronounced when the student after paying homage to the teacher.

(2) Awaken the attention of students

The activities that are rather difficult for informants to do are how to accommodate students who have different interests to arouse the attention of students following the learning process in the classroom.

(3) Appeciation

The results of documentation study on all PSP. In Tanete Rilau 3 Junior High School, Barru Regency always lists apperception activities on PSP. For example, repeating the results of past lessons without linking logically the relevance of the old 
subject to the new subject matter. According to Safruddin in interviewing researchers that those who act in appreciation, it can be seen that religious teachers take action in the form of tackling short lessons from past lessons to students.

The core activities of the lesson are limited to activities in the form of; giving key words, processing material along with examples, focusing attention, practical instructions to learn material, giving exercises related to the material, and providing feedback on the performance of students. The results of the PSP document study show that the core presentation in writing includes TKP delivery activities, material explanations and techniques for discussing subject matter. Observations made by researchers and student evaluations of core presentation activities are limited to the indicators listed in the following picture:

a. Keyword concept

Keywords are concepts, rules, core procedures, a subject that will be discussed at each meeting. The concept of keywords can be in the form of definitions of terms as well as information on prerequisites to clarify or retract memories of concepts that have been possessed by previous students, in the design of textbooks or dictates not specifically found in those key words.

b. Information Processing

Information processing basically has broad implications for various aspects of teaching. Information processing can be seen in terms of the application of teaching methods, it can be seen from the use of the media, can be seen in terms of the pattern of application of interaction, can be seen from the procedural stages of teaching from beginning to end, and can be chosen, from the mindset approach in this context, researchers observe the implementation of the information process in terms of the use of teaching methods and patterns of communication or interaction between teachers and students, and the delivery of the informants' thought flow.

c. Focusing on the attention of students

Focusing on the attention of students basically the implementation technique is not different from the attention withdrawal technique in the preliminary phase of learning. Focusing attention on core presentation is referring to the part of material that is temporarily presented. The results of the observation showed that the informants had different techniques between one informant and another. Recognition of learners through questionnaires on this issue generally assumes that every informant does it.

\section{(4) Practical Instructions for Studying Materials}

Activities regarding technical instructions in writing are not found in various written documents. However, the informants, namely informants R1 and R2, once gave technical instructions on how to learn how to slaughter animals in Islam. The actual technical guideline is also an act of guidance towards students, especially students who are somewhat lacking in their abilities, in this context the informant expresses one of the study guides one of the subjects. The results of the interview are as follows.

"The obstacles we face in class, especially certain subjects in PAI, are that some students need direct examples. In this case, I recommend students to observe people who slaughter qurban animals on holidays. God willing, this will provide technical knowledge. "And there are still many other examples that are often present in the community. (Basri, Principal of Tanete Rilau Middle School 3)

\section{(5) Giving training}

All informants used guidebooks from the school. The teachers carry out or assign students to work on worksheets that are on each subject. The work results of students are generally examined outside the teaching hours and there are even informants who bring the results of the LKS to their homes.

\section{(6) Feedback}

Giving feedback provided by informants is limited to the form of reinforcement or for example when the teacher gives questions to students, for students who answer correctly, informants say good! If the answer is not right said "not wrong but need additional explanation, in relation to the results of the work of the LKS, in most informants always provide feedback on the work results of students.

Based on the description above regarding the delivery of core learning activities, it can be seen that religious teachers carry out various types of core delivery activities to students with different emphasis points from one informant to another.

c) Closing learning activity

Organized all informants included closing activities on their PSP. The closing activities include giving assignments, giving tests, final and resume actions. The results of the observation indicate that the closing activities listed on the PSP are not always in accordance with what the informants did when closing activities. One of the reasons for the informants as stated in the results of the following interview: 
"Not all of what is stated in the lesson plan can be done specifically in relation to closing activities such as giving conclusions, giving final tests. Such things are caused due to time constraints, especially if we use discussion methods. (Basri, Principal of Tanete Rilau 3 Public Middle School )

Apart from the three closing activities, several activities were also observed related to the activities of the final stages of learning. The activity is described in the following information;

a. Giving formative tests

The purpose of giving formative tests to students is not to give good grades or not to students, but rather refers to the assessment of the learning process. This means whether the specific goals of learning are achieved or not. The results of the interview indicated that the provision of formative tests in the form of LKS was often carried out by the teacher concerned

b. Providing feedback on performance

Not all the subjects presented by the informants showed the activity of giving feedback to students. The observations show that feedback on the subject matter of the subject matter which contains psychomotor aspects, for example in the subject of prayer, especially second grade students, some of the students are asked to go to the front of the class to practice how each prayer movement and reading is practiced. When students do well at that time the informant conveys his assessment to all students. Conversely, if students who have not shown good performance, then the informant gives an assessment while teaching how to carry out parts of movements and readings that are not appropriate. Another example in the third grade is how informants give feedback on the subject of the study of the Qur'an towards students. In general, the informants who teach the Qur'an are starting by asking the learners randomly to take turns reading the verses of the Qur'an.

c. Giving follow up

Giving follow-up is a consequence of the results of an assessment of the exercises given to students. If the results of the work of students do not reach the target of mastery learning then remedial must be given. Whereas the results of the work of students who achieve the target of mastery learning should be given mated enrichment.

d. Repeat motivation

The activity of re-motivating students is hardly seen in the observation. and through the results of the interview the author re-motivates at the end of the lesson.

Based on the description and description of the activity indicators closing the above learning, it can be obtained an illustration that each informant performs action activities closing lessons with different frequencies between one informant and other informants, especially those relating to the provision of summaries.

1. The attitude of the teacher in the learning process

In addition to the organizing ability of the stages of the learning process, the attitudinal factors of both the teacher and students determine the process of successful learning that has been organized in such a way. In this section the attitude of the teacher is considered to influence the learning process as follows.

a. On time

Timely in starting lessons has a direct impact on students' discipline.

b. Timely in ending the lesson.

There are two problems that often occur in the learning process, namely the inaccuracy in ending the lesson. Sometimes there are teachers who finish teaching before their time, and there are those who do the opposite. Problems that arise in classrooms there are informants too late to start the lesson so that they are late in completing the lesson, so the teacher's of other subjects are reduced in time.

c. Dress neatly

The teacher's task is not only to transform knowledge into the minds of students, but more than that teachers are required to provide examples of examples to their students, including the problem of dressing. During the observation the informants were well-dressed in each teaching.

d. Open to objections from students

Democratic teachers are always open to all objections from students, because the teaching system has now begun to be directed at the "student center." In this study there were no visible students who gave objections to the teacher. Other objections seen in the observation were disclaimers between students. and students when discussions occur among them.

e. Be friendly to students

Being friendly to students is a teacher's approach to students. This approach can have an impact on students' behavior in relation to their social environment.

2. Use of Teaching Methods and Use of Learning Media 
The use of informant teaching methods as stated in their PSP is only limited to the lecture method, the question and answer method, the method of discussion and mastery. Then for the use of media in learning, informants generally use whiteboard, LCD, and textbook media. The intensity of the use of teaching methods and the use of learning media can be seen in the following table:

a. Use of the lecture method

The method used in serving mated at Tanete Rilau 3 Junior High School in Barru Regency is the lecture method. The lecture method is considered by teachers with subject characteristics. One of the characteristics is the nuances of aqeedah which must be approached with a very personal feeling approach that cannot be measured by a scientific measure. To provide such understanding must use lecture techniques, using an emotional approach.

b. Use of the question and answer method

The question and answer method developed by teachers at Tanete Rilau 3 Junior High School in Barru Regency is considered to be a technical presentation of material that can clarify problems that arise in face to face, so sometimes the question and answer if not well anticipated, sometimes causes material problems. not resolved at the meeting.

c. Use of discussion methods

The method of discussion in Tanete Rilau 3 Junior High School in Barru Regency, almost all the subjects are listed in the analysis of subject matter. Realization of face-to-face learning during the observations of researchers, shows always using the method of discussion.

d. Use of the play method

The method of role playing at Tanete Rilau 3 Junior High School in Barru Regency can actually be applied in several topics. But in the observation and analysis of the subject matter there was no inclusion of the method.

e. Use of teaching media

The use of learning media in learning in the Barru acceleration class, is quite good, in the observations of researchers there are seen several types of media such as white boards and black boards, textbooks or textbooks, dictates and LKS.

Based on the description and results of observations above relating to the activities of using the teaching method, it can be seen that the religious teacher or the informant uses the method of discussion and question and answer at most. The question and answer and discussion method is a method with a large enough frequency. Then for the role playing method and almost all informants rarely use it. On the side of using learning media, it can be seen that all teachers always use various types of media. The most commonly used media are LCD, whiteboard and textbooks. 6. The atmosphere of the Tanete Rilau 3 State Middle School Class in Barru Regency.

The atmosphere of the Tanete Rilau 3 State Middle School class in Barru Regency strongly supports the implementation of the learning process. Classes that are designed in such a way can influence the conducive learning process. From the results of observations in the class, it was seen that the class atmosphere was quite conducive because some classes were equipped with air conditioners. But some classes seem, not designed to adjust the use of various methods, for example the use of discussion methods. Such indication is seen when the informant delivered the material using the method of discussion with the seating arrangements of the students not changing. The position of the fixed seat lined up means that the views of the students are all ahead. They do not look at each other with one another, except students who are expressing their opinions.

In addition to the physical atmosphere, it also reflected the atmosphere of discipline of students participating in learning activities. Tanete Rilau 3 Junior High School in Barru District is fairly disciplined. The disciplinary indicators, among others, are seen in a strict system that is supervised by school guards. Tanete Rilau 3 Junior High School in Barru Regency has implemented strict discipline.

\section{Forms of Teacher's Efforts to Internalize Educational Values in Building Student Character}

The efforts of the Teacher in internalizing the values of education in fostering the character of students in Tanete Rilau 3 State Middle School through the observation that the behavioral phenomena of Tanete Rilau 3 Junior High School students in Barru Regency show signs of deterioration in the character of students, even though the symptoms not yet disturbing teachers and parents of students so that the phenomenon has not yet reached the level of crisis.

Therefore, as an act of normalizing commendable behavior, it is necessary to apply the right strategy as an effort made by Islamic Religious Education teachers to anticipate a crisis of character values. The question arises, how is the teacher's strategy in internalizing Islamic Education to anticipate the crisis of values or character of students? Answering this question the author interviewed teachers, principals, and several other teachers at Tanete Rilau 3 Public Middle School, Barru Regency, which was the location of this study.

The author formulates the form of teacher efforts in internalizing the values of Islamic education on character building through observations in the State Middle School 3 Tanete Rilau Barru Regency based on the findings of the field which includes; 


\section{a. Integrated Supervision}

The author got the opportunity to interview that in SMP Negeri 3 Tanete Rilau, Barru Regency, an integrated supervision of all school components was carried out on the behavior of students. Discipline of learning, prayer in congregation, time to enter and go home from school are all on time, learning behavior in class both students and teachers are monitored. However, it cannot be denied if there are students who commit minor offenses, but that cannot be categorized as characterless, to anticipate the occurrence of moral / character crises then as the headmaster asks all teachers to implement the PAIKEM strategy in implementing learning. In addition, it builds the synergy of teachers in developing the noble morality of students by integrating moral and moral values in each subject.

b. Giving motivation about advice and stories of successful people

The author conducted an interview with Mursani, arguing that to internalize the character values of students, we apply motivation through advice, stories of successful people. In addition, teachers do not only focus on efforts to build methodological abilities in terms of religious knowledge, but no less important is to build cooperation or synergy among teachers to help pay attention to student behavior. Because this is the duty of every teacher.

\section{c. Implementing Learning Strategies with the PAIKEM Model}

While the strategy that needs to be done in internalizing the values of the character of students in SMP Negeri 3 Tanete Rilau, Barru Regency is to apply the PAIKEM strategy appropriately, review the mastery of learning methodology, build cooperation between teachers and parents of students. Therefore, the connecting card needs to be reactivated, in schools there needs to be a special place for moral formation outside of school hours.

Referring to the findings in the field, the results of interviews that the author obtained from Hj Nurhayati, that the problem of the character of students in Tanete Rilau 3 Junior High School in Barru Regency basically cannot be categorized critically, because their actions which are considered violations are only carried out by a small number of students and not Serious violations such as stealing, fighting, against the teacher, but only like going out of class at the time of study and never re-entering so that the violation can still be overcome internally. However, attention needs to be taken in order not to develop into a serious or moral crisis. Therefore we ask all teachers that character education is the responsibility of every teacher, not just a religious teacher. Furthermore, in this school learning based on ICT (Information, and Communication Technology) and Web-based is intended to provide services to all parties to be able to access the development of schools and students.

\section{d. Extra-Curricular Activities}

Through the observation that the behavioral conditions of the students as mentioned above, the author obtained an explanation that the learning strategy model applied in this school in internalizing character values in students in Tanete Rilau 3 Junior High School in Barru District was to carry out learning outside of school hours through extracurricular activities. The teacher applies habituation and parenting methods. In addition, it is scheduled to provide religious consultation services for students in each school. Religious consultation services for students at Tanete Rilau 3 Middle School in Barru Regency have been running even though they have not been maximized. This activity is a follow-up to the agreement of the Counseling Guidance (BK) teachers and teachers at Tanete Rilau 3 Middle School in Barru Regency.

\section{e. Establish a Study Group}

The results of the author's interview that the learning process refers to the process approach, while the strategy developed to internalize character values in students is to form group learning activities accompanied by teachers who are competent in their fields.

In addition, the author had the opportunity to interview $\mathrm{Hj}$ Nurhayati, she said that in, after finishing the flag ceremony on Monday a coordination meeting of school leaders, teachers / homerooms and BK was held. Meeting material is a matter of implementing learning, the compactness of all school components in the moral development of students. The problem of violations of school discipline is resolved through a mechanism in stages, namely, homeroom, BK and or with parents of students.

According to the researcher that the SMP Negeri 3 Tanete Rilau in Barru Regency needs to be anticipated to not occur 1 increase in the quality of deviations in character values in the implementation of education in schools, and as a teacher highly respects the impact of technological sophistication and the entry of foreign culture in Barru, it is not impossible to influence the psychological development of participants I students. Therefore, teachers at SMP Negeri 3 Tanete Rilau, Barru Regency carry out extracurricular learning. Build cohesiveness with parents of students, especially when the beginning of the school year through school committee meetings. 
The right teacher strategy in implementing learning according to $\mathrm{Hj}$. Kusmiati can contribute to the formation of student competencies. However, it would be better if parents at home provide reinforcement-strengthening of the religious knowledge they receive in school. Because their experience is more in touch with the environment outside of school. So the teacher of Tanete Rilau Middle School 3 in Barru Regency uses a kind of connecting card as a strategy that can build good interaction and communication between teachers and parents in building quality religious education.

Hj. Kusmiati gave a statement that the weakness of learning in Islamic Education which was highlighted by several parties was the performance of teachers who had not carried out their professional duties as professional teachers, teaching was still like before obtaining a professional teacher certificate. So according to her, if the teacher wants to succeed in integrating cognitive, affective, and psychomotor competencies, students really need to apply the right strategy, for example the PAIKEM strategy, because this strategy is already familiar to teachers, which is important because there is a willingness to change habits.

According to the researcher that in the framework of forming the character of students in Middle School 3 of Barru Regency, it cannot only rely on the teaching ability of the teacher, but also the teacher must position himself as an example, balance theory with practice, always given advice. In addition, the teacher must build synergy between teachers to help pay attention to the behavior of students. The author assumes that the strategies carried out are related to the need to integrate cognitive, affective aspects, and psychomotor aspects in learning Islamic Education so that students can behave with good morals, namely working with uraum teachers in building togetherness in fostering the character and morals of students, for example through extracurricular activities internalize religious values so as to create a religious atmosphere in life in school. Even parents are involved in participating in these activities.

\section{Conclusion}

Research Findings "To Madeceng Pangampe" Anthropological Studies of Character Formation in Students in Barru Regency can be seen in several forms, among others; First, the values in education that are relevant to Bugines cultural values have been socialized to students in each lesson. Like the value of honesty (clay), kepatautan value (asitinajang), the value of constancy (getting), shame (siri '), the value of social security (assitulungeng). Second, the efforts of teachers in teaching practices in instilling cultural values are contained in many learning methods. Among each RPS of learning in students, these cultural values are inserted in the form of material, as well as in the form of learning methods. Third, the form of teachers' efforts to internalize Bugines cultural values in fostering the character of students in Tanete Rilau 3 Public Middle School, Barru Regency, through integrated supervision of all school components towards student behavior, giving motivational advice and stories of successful people, applying learning strategies, increase extra activities, and form learning groups because generally students who have high achievements also have good character attitudes.

\section{E. Bibliography}

Abbott, Tina. 2005. Social and Personality Development. Published by Taylor \& Francis Group e-Library.

Al-Ghazali. 2000. Ihya 'Ulum Ad-Din. Translation without translator name. Charisma Publisher.

Brannen, Julia. 1997. Combining Qualitative and Quantitative Research Methods. Translation of the original title Mixing Methods; Qualitative and Quantitative Research by H. Nuktah Arfawie Kurde, Imam Safe'i, and Noorhaidi A.H. Imam Safe'i (Editor). Student Library Publishers collaborated with Antasari Samarinda's IAIN Tarbiah Faculty.

Bungin, Burhan (Editor). 2004. Qualitative Research Methodology; Methodological Actualization to the Variety of Contemporary Variants. RajaGrafindo Persada Publisher.

Eller, Jack David. 2009. Cultural Anthropology; Global Forces, Local Issues. Taylor \& Francis Group.

Ember, Carol R. and Melvin Ember. Theories and Methods of Cultural Anthropology. Posts are contained in T.Ohromi (Editor). 1999. Principles of Cultural Anthropology. Publisher of the Indonesian Torch Foundation.

Endraswara, Suwardi. 2003. Cultural Research Methodology. Gadjah Mada University Press Publisher.

Flanagan, Cara. 2002. Early Socialization; Sociability and Attachment. Published by Taylor \& Francis Group e-Library.

Gordon, R.G. 2005. Personality. Published by Taylor \& Francis e-Library.

Joni, T. Raka. Educating Learning; Conceptual Articulation, Contextual Applied and Empirical Verification. Writing was published in the Journal of Educational Sciences. Volume 12. Number 02. 2005. Publishers of Educational Institution Education Institutions (LPTK) and Indonesian Bachelor of Education Association (ISPI). 
Keesing, Roger M. 1999. Cultural Anthropology; A Contemporary Perspective. Volume I. Translation of the original title of Cultural Anthropology; a Contemporary Perspective by Samuel Gunawan. Erlangga Publisher.

Koentjaraningrat. 1974. Culture, Mentality and Development. Gramedia Publisher.

Mattulada (a). Bugis-Makassar Man and Culture and Kaili in Sulawesi. Writing was published in the Indonesian Anthropology Journal. Number 48. year XV. January-April 1991. Publisher of the Anthropology Department, FISIP UI.

Mattulada (b). Siri 'and Cultural Coaching. Writing was published in the Indonesian Anthropology Journal. Number 48. year XV. January-April 1991. Publisher of the Anthropology Department, FISIP UI.

Miles, Matthew B. and A. Michael Huberman. 1994. Qualitative Data Analysis. Sage Publications Publisher.

Moleong, Lexy. 1993. Qualitative Research Methodology. Teen Publisher Rosdakarya - Bandung.

Patton, Michael Quinn. 2002. Qualitative Research \& Evaluation Methods. Sage Publication.

Poerwadarminta, W.J.S. 1993. General Dictionary of Indonesian. Balai Pustaka Publisher.

Ridjal, Tajroel. Bricolage Method in Social Research. Posts are published in Burhan Bungin (Editor). 2004. Qualitative Research Methodology; Methodological Actualization to the Variety of Contemporary Variants. RajaGrafindo Persada Publisher.

Rahman, Nurhayati., 2009. Bugis Human Environment Wisdom: Based on the Mpaloe Meow Manuscript. Publisher La Galigo Press, Makassar.

Ringer, Fritz. 1997. Max Weber's Methodology; the Unification of the Cultural and Social Sciences. Harvard University Press.

Saifuddin, Achmad Fedyani. 2005. Contemporary Anthropology; A Critical Introduction to the Paradigm. Prenada Media Publisher.

Samani, Muchlas and Harianto. 2013. Character Education; Concept and Model of Character Education. Teen Publisher Rosdakarya.

Sanjek, Roger (editor). 2009. Fieldnotes; the Makings of Anthropology. Cornell University Press.

Salam, Rahayu., Assitulunggeng: Form Please Help In an Akikah Ceremony on Salem Island. In the Walasuji Journal. Vol.5.No.2. December 2014; 327-339.

Schwartz, Theodore. Where is the Culture? Personality as the Distributive Locus of Culture. Writing is published in George D. Spindler (Editor). 1980. The Making of Psychological Anthropology. University of California Press.

Shaffer, David R. 2009. Social and Personality Development. Wadsworth Cengage Learning.

Sudikan, Setya Yuwana. 2001. Cultural Research Methods. Image Discourse Publishers.

Sudikan, Setya Yuwana. Variety of Data Collection Methods, Reviewing Observations, Interviews, Life History Analysis, Folklor Analysis. Posts are published in Burhan Bungin (Editor). 2004. Qualitative Research Methodology; Methodological Actualization to the Variety of Contemporary Variants. RajaGrafindo Persada Publisher.

Sunawan. Some Forms of Underachievement Behavior from the Self Regulated Learning Theory Perspective. Writing was published in the Journal of Educational Sciences. 2005. Volume 12. Number 2. Publishers of Educational Institution Education Institutions (LPTK) and Indonesian Bachelor of Education Association (ISPI).

Tang, Mahmud., 1987. Acting Alone: A Bugis Social-Cultural System. University of Indonesia Thesis.

., 1997. Bugis Culture: Upholding Siri. In the System Book Indonesian Culture (ed) M. Yunus Melalatoa. Jakarta. PT. Pemator .

„. 1996. Variety of Knowledge on Social Security at the Former Great Kingdom of South Sulawesi, Indonesia. Wageningen-Netherlands: Grendisch Service Centrum Van Gills B.V.

2007. Cultural Values in Regional Literature Underlying Traditional Ethnic Bugis Social Securities. In the Proceedings of the International Congress of Regional Languages of South Sulawesi, Makassar. 